\title{
Analisis Pencatatan dan Pelaporan Aset Tetap Pada Pemerintah Kabupaten Kepulauan Sangihe Tahun 2011 (Studi Kasus pada Dinas PPKAD selaku SKPKD)
}

\author{
Deasy Anastasia Mogi \\ Jenny Morasa
}

\begin{abstract}
Local governments are reguired to make accountability reports that use accounting system that is set by the central government in the form of law - laws and regulations that are binding on all Government local government. Therefore, each Regional Financial Management Unit (SKPKD) must prepare its financial statements based on the government regulation number 24 of the Minister of home affairs Number 59 year 2007, which is an amandement to Permendagri N0. 13 year 2006 on guidelines financial Management.

The research was conducted in Sangihe regency, which in this study, analyzed fixed asset Recording and Reporting on Local Government in this case the Departement of finance and revenue management as a Regional Asset SKPKD for fiscal year 2011.

The purpose of this study is to analyzed the suitability of the recording and reporting of fixed assets in Sangihe regency government especially the Departement of revenue in the finance and asset management areas as SKPKD to financial statements in financial report balance Sangihe islanda District government with government regulation No. 24 year 2005 on standards government accounting and No. 13 year 2006 on Regional Financial Management Guidelslines.

The study uses a descriptive research design in the form of case studies. Type of data used is quantitative data that figures-figures in the Balance sheet. The author uses the method library research, field surveys, and documentation required for data collection.

The results showed that, Sangihe regency government has done the recording and reporting of fixed assets with good, though not fully in accordance with government Regulation No. 24 year 2005 regarding the Regulation of the minister and the government accounting standards of 2007 because the 2011 financial statements opinion gets no opinion (Disclaimer Opinion) by CPC caused by asset accounting. However, the financial statements have been prepared in time to be used for the users as decision makers and as refence for the preparation of financial statements with fiscal year 2012 and in accordance with government accounting standards.
\end{abstract}

Key Word: Fix Asset 


\section{PENDAHULUAN}

\subsection{Alasan Pemilihan Judul}

Perkembangan akuntansi sektor publik di Indonesia sebelum era reformasi dapat dinilai kurang pesat. Pada waktu itu, akuntansi sektor publik kurang mendapat perhatian yang serius. Orientasi pembangunan lebih banyak diarahkan pada pembangunan sektor industri (bisnis) dan cenderung mengarahkan pembangunan sektor publik.

Akuntansi Keuangan Pemerintahan Daerah di Indonesia merupakan salah satu bidang dalam akuntansi sektor publik yang mendapat perhatian besar dari berbagai pihak semenjak reformasi Tahun 1998. Pengelolaan keuangan daerah merupakan salah satu bagian yang mengalami perubahan mendasar dengan ditetapkannya UU No. 32 tahun 2004 tentang Pemerintahan Daerah dan UU No. 33 tahun 2004 tentang Perimbangan Keuangan antara Pemerintah Pusat dan Pemerintah Daerah.

Pemerintah Daerah diwajibkan menyusun laporan pertanggungjawaban yang menggunakan sistem akuntansi yang diatur oleh pemerintah pusat dalam bentuk Undang-undang dan Peraturan Pemerintah yang bersifat mengikat seluruh Pemerintah Daerah. Dalam upaya mewujudkan pemerintah yang transparan dan akuntabel dibutuhkan adanya satu jaminan bahwa segala aktivitas dan transaksi pemerintah terekam secara baik dengan ukuran-ukuran yang jelas dan dapat diikhtisarkan melalui proses akuntansi dalam bentuk laporan, sehingga bisa dilihat segala yang terjadi dan yang terdapat dalam ruang entitas pemerintahan tersebut. Menurut Peraturan Pemerintah Nomor 24 Tahun 2005 tentang Standar Akuntansi Pemerintahan (SAP) Pernyataan Nomor 07, menjelaskan aset tetap adalah sumber daya ekonomi yang dikuasai dan /atau dimiliki oleh pemrintah sebagai akibat dari peristiwa masa lalu dan dari mana manfaat ekonomi dan/atau sosial dimasa depan diharapkan dapat diperoleh, baik oleh pemerintah mauoun masyarakat, serta dapta diukur dalam satuan uang, termasuk sumber daya non-keuangan yang diperlukan untuk penyediaan jasa bagi masyarakat umum dan sumber daya yang dipelihara karena alasan sejarah bukan budaya.

Aset tetap sering merupakan suatu bagian utama aset pemerintah, dan karenanya signifikan dalam penyajian neraca. Termasuk aset tetap pemerintah yang dimiliki oleh entitas pelaporan namun dimanfaatkan oleh entitas lainnya, misalnya instansi pemerintah lainnya, universitas, kontraktor, hak atas tanah. Tidak termasuk definisi aset tetap adalah aset yang dikuasai untuk dikonsumsi dalam operasi pemerintah, seperti bahan (materials) dan perlengkapan (supplies).

Dinas Pendapatan Pengelolaan Keuangan dan Aset Daerah (PPKAD) yang merupakan Satuan Kerja Pengelola Keuangan Daerah (SKPKD) yang ada di wlayah pemerintah Kabupaten Kepulauan Sangihe selaku pengelola keuangan daerah harus membuat laporan pertanggungjawaban atas kewenangan yang dilaksanakannya kepada Kepala Daerah, sesuai dengan Peraturan Pemerintah Nomor 24 Tahun 2005 tentang Standar Akuntansi Pemerintahan dan Permendagri No. 59 Tahun 2007, yang merupakan perubahan atas Permendagri No. 13 Tahun 2006 tentang Pedoman Pengelolaan Keuangan Daerah. Dari alasan pemilihan judul di atas maka penulis ingin menganalisis tentang Pencatatan dan Pelaporan Keuangan yang dalam hal ini mengenai Aset Tetap pada Pemerintah Kabupaten Kepulauan Sangihe dalam hal ini adalah Dinas Pendapatan Pengelolaan Keuangan dan Aset Daerah (PPKAD) yang dituangkan dalam bentuk laporan akhir yang berjudul "Analisis Pencatatan dan Pelaporan Aset Tetap Pada Pemerintah Kabupaten Kepulauan Sangihe Tahun 2011 (Studi Kasus pada Dinas PPKAD selaku SKPKD)".

Tujuan danri penelitian ini adalah untuk mengetahui Apakah Pemerintah Kabupaten Kepulauan Sangihe telah melakukan pencatatan akuntansi dan pelaporan aset tetap keuangan dengan baik, sesuai dengan Peraturan Pemerintah Nomor 24 Tahun 2005 tentang Standar Akuntansi Pemerintahan dan Permendagri No. 59 Tahun 2007 tentang Pedoman Pengelolaan Keuangan Daerah.

Data yang telah diperoleh akan dianalisis dengan metode deskriptif dalam bentuk studi kasus yaitu suatu metode yang bertujuan untuk membuat gambaran secara sistematis, faktual dan akurat mengenai fakta-fakta, dengan membandingkan antara sistem pelaporan keuangan aset tetap yang dilaksanakan di SKPKD dalam hal ini adalah Dinas Pendapatan Pengelolaan Keuangan dan Aset 
Daerah Kabupaten Kepulauan Sangihe, dengan Standar Akuntansi Pemerintahan dan Permendagri No. 59 Tahun 2007 tentang Pedoman Pengelolaan Keuangan Daerah.

\section{LANDASAN TEORI}

\subsection{Konsep Akuntansi Pemerintahan}

Menurut Peraturan Pemerintah Nomor 24 Tahun 2005 tentang Standar Akuntansi Pemerintahan, akuntansi adalah proses pencatatan, pengukuran, pengklasifikasian, pengikhtisaran transaksi dan kejadian keuangan, penginterpretasian atas hasilnya, serta penyajian laporan.

\subsection{Pengelolaan Keuangan Daerah}

Menurut PP Nomor 58 Tahun 2005 tentang Pengelolaan Keuangan Daerah, Keuangan Daerah adalah semua hak dan kewajiban dalam rangka penyelenggaraan pemerintah daerah yang dapat dinilai dengan uang termasuk didalamnya segala bentuk kekayaan yang berhubungan dengan hak dan kewajiban daerah tersebut, sedangkan Pengelolaan Keuangan Daerah menurut PP Nomor 58 Tahun 2005 adalah keseluruhan kegiatan yang meliputi perencanaan, pelaksanaan, penatausahaan pelaporan, pertanggungjawaban dan pengawasan keuangan daerah.

\subsection{Akuntansi Keuangan Daerah pada Satuan Kerja Pengelola Keuangan Daerah (SKPKD)}

Dalam konstruksi keuangan daerah terdapat dua jenis satuan kerja yaitu:

1. Satuan Kerja Perangkat Daerah (SKPD)

2. Satuan Kerja Pengelola Keuangan Daerah (SKPKD)

\subsection{Aset Tetap}

Aset adalah sumber daya ekonomi yang dikuasai dan/atau dimiliki oleh pemerintah sebagai akibat dari peristiwa masa lalu dan dari mana manfaat ekonomi dan/atau sosial di masa depan diharapkan dapat diperoleh, baik oleh pemerintah maupun masyarakat, serta dapat diukur dalam satuan uang, termasuk sumber daya keuangan yang diperlukan untuk penyediaan jasa bagi masyarakat umum dan sumber-sumber daya yang dipelihara karena alasan sejarah dan budaya.

Aset tetap adalah aset berwujud yang mempunyai masa manfaat lebih dari 12 bulan untuk digunakan dalam kegiatan pemerintah atau dimanfaatkan oleh masyarakat umum.

Aset tetap sering merupakan suatu bagian utama aset pemerintah, dan karenanya signifikan dalam penyajian neraca. Termasuk dalam aset tetap pemerintah adalah :

a. Aset tetap yang dimiliki oleh entitas pelaporan namun dimanfaatkan oleh entitas lainnya.

b. Hak atas tanah.

Tidak termasuk dalam definisi aset tetap adalah aset yang dikuasai untuk dikonsumsi dalam operasi pemerintah, seperti bahan (materials) dan perlengkapan (supplies).

\section{GAMBARAN UMUM OBJEK PENELITIAN}

\subsection{Deskripsi Objek Peneiltian}

Penelitian ini dilakukan pada Dinas Pendapatan dan Pengelolaan aset Daerah (DPPKAD) selaku SKPKD yang ada di Pemerintah Kabupaten Kepulauan Sangihe.

\section{HASIL ANALISIS DAN PEMBAHASAN}

\subsection{Analisis}

Neraca menggambarkan posisi keuangan pemerintah mengenai aset, kewajiban, dan ekuitas dana pada tanggal tertentu. Unsur yang dicakupkan oleh neraca terdiri dari aset, kewajiban, dan ekuitas dana.

Berdasarkan data penelitian, Neraca Pemerintah Kabupaten Sangihe untuk Tahun Anggaran 2011, menunjukkan bahwa :

Tahun 2011, Aset yang dimiliki Pemerintah Kabupaten Kepulauan Sangihe senilai Rp 999.452.205.988,98 yang terdiri dari :

a. Aset Lancar Rp. 48.557.782.857,81 
b. Investasi jangka panjang Rp. 9.936.747.217,17

c. Asset Tetap Rp. 930.996.184.269,00 yang terdiri dari:

1. Tanah, Rp. 39.324.767.362,00

2. Peralatan dan Mesin, Rp. 139.183.628.481,00

3. Gedung dan Bangunan, Rp. 317.029.650.684,00

4. Jalan, Irigasi, dan Instalasi, Rp. 422.408.780.447,00

5. Aset Tetap lainnya, Rp. 8.944.825.115,00

6. Konstruksi Dalam Pengerjaan, Rp. 4.104.532.180,00

7. Akumulasi Penyusutan, Rp. 0,00

Total kewajiban yang dimiliki Rp. 2.415.529.719,76 yang merupakan kewajiban jangka pendek sedangkan untuk kewajiban jangka panjang Rp. 0,00.

Dan untuk Ekuitas Dana berjumlah Rp. 997.036.676.269,22 yang terdiri dari :

a. Ekuitas Dana Lancar Rp. 46.142.253.138,05

b. Ekuitas Dana Investasi Rp. 950.894.423.131,17

c. Ekuitas Dana Cadangan Rp. 0,00

Total Kewajiban dan Ekuitas adalah Rp. 999.452.205.988,98

\subsection{Pembahasan}

\subsubsection{Pencatatan}

Aset tetap sering merupakan suatu bagian utama aset pemerintah, dan karenanya signifikan dalam penyajian neraca. Aset tetap dinilai dengan biaya perolehan. Pada penelitian ini yang menjadi fokus utama dalam aset tetap adalah aset tetap tanah. Tanah merupakan salah satu aset tetap yang ada pada pemerintah dan tanah yang diperoleh dengan maksud untuk dipakai dalam kegiatan operasional pemerintah dan dalam kondisi siap dipakai. Pencatatan aset tetap tanah yang dicatat pemerintah Kabupaten Kepulauan Sangihe pada tahun 2011 seperti dibawah ini:

Jurnal pengeluaran kas untuk aset tetap tanah:

1. $\mathrm{R} / \mathrm{K}$ SKPD $\quad \mathrm{xxx}$

Kas $\mathrm{xxx}$

(Pembayaran belanja modal biaya ganti rugi tanah lokasi Kantor Lurah Kolongan Akembawi Kec. Tahuna Barat).

2. $\mathrm{R} / \mathrm{K}$ SKPD $\quad \mathrm{xxx}$

Kas $\quad \mathrm{xxx}$

(Pembayaran belanja modal biaya ganti rugi tanah lokasi Jalan masuk Pelabuhan Perintis Kahakitang Kecamatan Tatoareng).

3. $\mathrm{R} / \mathrm{K}$ SKPD $\mathrm{xxx}$

Kas $\quad \mathrm{xxx}$

(Pembayaran belanja modal biaya ganti rugi tanah lokasi tempat pembuangan akhir (TPA) sampah Kelurahan Santiago Kec. Tahuna).

4. $\mathrm{R} / \mathrm{K}$ SKPD $\mathrm{xxx}$

Kas $\quad$ xxx

(pembayaran belanja modal tanah sarana umum Pasar Lokasi Pasar Naha (lanjutan)).

5. $\mathrm{R} / \mathrm{K}$ SKPD $\mathrm{xxx}$

Kas $\quad x x x$

(Pembayaran belanja modal tanah lokasi Petugas Areal Pelabuhan Peta(lanjutan)).

6. $\mathrm{R} / \mathrm{K}$ SKPD $\quad \mathrm{xxx}$

Kas $\quad$ xxx

(Pembayaran belanja modal tanah lokasi SMK Pertanian(lanjutan) Kec. Tabukan Selatan Tengah). Jurnal Korolari:

1. Tanah Kantor $\quad \mathrm{xxx}$

Diinvestasikan Dalam Aset Tetap $\quad$ xxx 
2. Tanah Kantor $\quad \mathrm{xxx}$

Diinvestasikan Dalam Aser Tetap $\quad$ xxx

3. Tanah Sarana Umum Tempat Pembuangan Akhir Sampah $\quad$ xxx

Diinvestasikan Dalam Aset Tetap

$\operatorname{xxx}$

4. Tanah Sarana Umum Pasar

$\operatorname{xxx}$

Diinvestasikan Dalam Aset Tetap $\quad$ xxx

5. Tanah Kantor

$\operatorname{xxx}$

Diinvestasikan Dalam Aset Tetap xxx

6. Tanah Sarana Pendidikan Menengah Umum dan Kejuruan xxx

Diinvestasikan Dalam Aset Tetap

XXX

\section{Tabel 4.4}

BUKU BESAR

PEMRINTAHAN KABUPATEN KEPULAUAN SANGIHE

Urusan Pemerintahan

Bidang Pemerintahan

Unit Organisasi

Sub Unit Organisasi

Kode Rekening Buku besar

Nama Rekening Buku Besar
: Urusan Wajib

: Otonomi Daerah, Pemerintahan Umum, Administrasi

Keuangan Daerah, Kepegawaian, dan Persandian

: Sekretariat Daerah

: Bagian Administrasi dan Umum

\begin{tabular}{|c|l|c|c|c|c|}
\hline Tanggal & Uraian & Ref & Debet (Rp) & Kredit (Rp) & Saldo (Rp) \\
\hline $\mathrm{xx} / \mathrm{xx} / 20 \mathrm{xx}$ & Saldo Awal & 1 & & & $\mathrm{xxx}$ \\
$\mathrm{xx} / \mathrm{xx} / 20 \mathrm{xx}$ & Jurnal Umum-Korolari & 1 & $\mathrm{xxx}$ & & \\
$\mathrm{xx} / \mathrm{xx} / 20 \mathrm{xx}$ & Jurnal Umum-Korolari & 1 & $\mathrm{xxx}$ & & \\
$\mathrm{xx} / \mathrm{xx} / 20 \mathrm{xx}$ & Jurnal Umum-Korolari & 1 & $\mathrm{xxx}$ & & \\
$\mathrm{xx} / \mathrm{xx} / 20 \mathrm{xx}$ & Jurnal Umum-Korolari & 1 & $\mathrm{xxx}$ & & \\
$\mathrm{xx} / \mathrm{xx} / 20 \mathrm{xx}$ & Jurnal Umum-Korolari & 1 & $\mathrm{xxx}$ & & \\
$\mathrm{xx} / \mathrm{xx} / 20 \mathrm{xx}$ & Jurnal Umum-Korolari & 1 & $\mathrm{xxx}$ & & \\
& & & & & \\
& & & $\mathrm{Rp.xxx}$ & $\mathrm{Rp} .-$ & $\mathrm{Rp.} \mathrm{xxx}$ \\
\hline
\end{tabular}

Hasil olahan data DPPKAD 
Tabel 4.5

PEMERINTAH KABUPATEN KEPULAUAN SANGIHE BUKU BESAR PEMBANTU

Urusan Pemerintahan

Bidang Pemerintahan
: Urusan Wajib

: Otonomi Daerah, Pemerintahan Umum, Administrasi

Keuangan Daerah, Kepegawaian dan Persandian

: Sekretariat Daerah

Unit Organisasi

Kode rekening buku besar

Nama rekening buku besar pembantu:

\begin{tabular}{|c|c|c|c|c|c|c|c|}
\hline \multirow[b]{2}{*}{ No } & \multirow[b]{2}{*}{ Tgl } & \multicolumn{2}{|c|}{ Referensi } & \multirow[b]{2}{*}{ Uraian } & \multirow[b]{2}{*}{ Debet } & \multirow[b]{2}{*}{ Kredit } & \multirow[b]{2}{*}{ Saldo } \\
\hline & & $\begin{array}{l}\text { No. } \\
\text { Bukti }\end{array}$ & $\begin{array}{l}\text { Kode } \\
\text { Rek. } \\
\text { Lawan } \\
\end{array}$ & & & & \\
\hline & & & & $\begin{array}{l}\text { Saldo awal } \\
\text { Diinvestasikan dalam aset tetap } \\
\text { Diinvestaikan dalam aset tetap } \\
\text { Diinvestasikan dalam aset tetap } \\
\text { Diinvestasikan dalam aset tetap } \\
\text { Diinvestasikan dalam aset tetap } \\
\text { Diinvestasikan dalam aset tetap }\end{array}$ & $\mathrm{xxx}$ & $\begin{array}{l}\mathrm{xxx} \\
\mathrm{xxx} \\
\mathrm{xxx} \\
\mathrm{xxx} \\
\mathrm{xxx} \\
\mathrm{xxx}\end{array}$ & \\
\hline & & & & Jumlah & $\mathrm{xxx}$ & $\mathrm{xxx}$ & \\
\hline
\end{tabular}

Hasil olahan data DPPKAD

Tabel 4.6

PEMERINTAH KABUPATEN KEPULAUAN SANGIHE

NERACA SALDO

31 DESEMBER 20xx

\begin{tabular}{|c|l|c|c|}
\hline $\begin{array}{c}\text { Kode } \\
\text { Rekening }\end{array}$ & \multicolumn{1}{|c|}{ Uraian } & \multicolumn{2}{|c|}{ Jumlah } \\
\cline { 2 - 4 } & Kas & Debet & Kredit \\
\hline & $\begin{array}{c}\text { Aset Tetap- Tanah } \\
\text { Dinvestasikan dalam Aset Tetap }\end{array}$ & \\
& \multicolumn{1}{|c|}{ Jumlah } & & $\mathrm{xxx}$ \\
\hline
\end{tabular}

Hasil olahan data DPPKAD

Untuk Tahun Anggaran 2011, akuntansi aset untuk Pemerintah Kabupaten Kepulauan Sangihe diberi opini tidak memberikan pendapat (Disclaimer Opinion) oleh BPK, karena adanya penyalahgunaan sejumlah aset tetap oleh Pemeritah Kabupaten Kepulauan Sangihe.

Berdasarkan hasil pemeriksaan tahun anggaran 2010, tanah yang belum memiliki sertifikat sebanyak 107 jenis tanah dengan nialai sebesar Rp. 16.399.005.936,00 dan 32 jenis tanah telah didukung dengan sertifikat atas 119 bidang tanah dengan nilai sebesar Rp. 22.908.661.426,00. Pada tahun 2011 pemerintah daerah melalui sekertariat Daerah mengadakan pengadaan dua bidang tanah kantor senilai Rp. 17.100.000,00, atas pembelian tersebut belum didukung dengan sertifikat tanah. Dari hasil pemeriksan terhadap dokumen kepemilikkan tanah diketahui bahwa selama tahun 2011 belum ada penambahan sertifikat tanah hal ini juga tidak sesuai dengan Peraturan Pemerintah Nomor 24 Tahun 2005 tentang Standar Akuntansi Pemerintahan Nomor 7 paragraf 72 
Tabel 4.7

Ringkasan Hasil Analisis Pencatatan Aset Tetap-Tanah pada Pemerintah Kabupaten Kepulauan Sangihe (yang dilakukan oleh Dinas PPKAD selaku SKPKD) untuk Laporan Keuangan Tahun 2011

\begin{tabular}{|l|l|l|l|l|l|}
\hline $\begin{array}{l}\text { N Prosedur } \\
\mathbf{0}\end{array}$ & $\begin{array}{l}\text { Pencatatan PPKD Kab. } \\
\text { Kep Sangihe (contoh } \\
\text { jurnal yang ada) }\end{array}$ & $\begin{array}{l}\text { SAP N 24 } \\
\text { PP No 24 } \\
\text { Tahun } \\
\mathbf{2 0 0 5}\end{array}$ & $\begin{array}{l}\text { Permendagri } \\
\text { No. 59 tahun } \\
\mathbf{2 0 0 7}\end{array}$ & Ket \\
\hline 1 & $\begin{array}{l}\text { Akuntansi } \\
\text { Aset }\end{array}$ & $\begin{array}{l}\text { Belanja Modal-Tanah } \\
\text { Kas di Kas Daerah } \\
\text { Jurnal Korolari }\end{array}$ & $\begin{array}{l}\text { Tidak } \\
\text { sepenuhnya } \\
\text { sesuai } \\
\text { (pengakuan aset tetap): } \\
\text { Aset tetap-Tanah } \\
\text { Diinvestasikan pd aset } \\
\text { tetap }\end{array}$ & $\begin{array}{l}\text { Tidak } \\
\text { sepenuhnya } \\
\text { sesuai }\end{array}$ & $\begin{array}{l}\text { Aset tetap tanah } \\
\text { tidak sesuai dengan } \\
\text { ketentuan yaitu } \\
\text { terdapat tanah yang } \\
\text { belum didukung } \\
\text { oleh bukti } \\
\text { kepemilikan (SAP } \\
\text { N0. 7) }\end{array}$ \\
\hline
\end{tabular}

Sumber : Hasil Data Olahan Tahun 2011

\subsubsection{Analisis Laporan Keuangan}

Pemerintah Kabupaten Kepulauan Sangihe pada umumnya telah menyusun Laporan Keuangan tahunan sesuai dengan Peraturan Pemerintah Nomor 24 Tahun 2005 tentang Standar Akuntansi Pemerintahan dan Peraturan Menteri Dalam Negeri (Permendagri) Nomor 59 Tahun 2007, yang merupakan perubahan atas Permendagri No. 13 Tahun 2006 tentang Pedoman Pengelolaan Keuangan Daerah

\section{KESIMPULAN DAN SARAN}

\subsection{Kesimpulan}

1. Pemerintah Kabupaten Kepulauan Sangihe pada umumnya telah melakukan pencatatan akuntansi aset dalam hal ini akuntansi aset tetap yang baik, sesuai dengan PP No. 24 Tahun 2005 Tentang Standar Akuntansi Pemerintahan dan Permendagri No. 59 Tahun 2007 tentang Pedoman Pengelolaan Keuangan Daerah. Namun, Pada Tahun 2011 belum sepenuhnya sesuai dengan Standar Akuntansi Pemerintahan Nomor 7 paragraf 72 (dalam aset tetap tanah, masih banyak tanah yang belum memiliki bukti kepemilikan/sertifikat dan juga aset tetap yang diserahkan pada pemerintah pusat masih tercatat sebagai aset pemerintah daerah dan adanya penyalahgunaan sejumlah aset di Daerah Kabupaten Kepulauan Sangihe) tetapi karena minimnya informasi yang diberikan maka tidak diketahui bahwa aset tetap apa yang disalahgunakan oleh Pemerintah Kabupaten Kepulauan Sangihe yang menyebabkan laporan keuangan tidak memberikan pendapat (Disclaimer Opinion).

2. Untuk Laporan Keuangan Tahun 2011 karena pada akuntansi aset, aset tetap tanah, masih banyak tanah yang belum memiliki bukti kepemilikan/sertifikat dan juga aset tetap yang diserahkan pada pemerintah pusat masih tercatat sebagai aset pemerintah daerah, sehingga laporan audit oleh BPK tidak memberikan pendapat (Disclaimer Opinion), maka Laporan Keuangan Kabupaten Kepulauan Sangihe tidak sesuai dengan Standar Akuntansi Pemerintahan.

\subsection{Saran}

Pemerintah Kabupaten Kepulauan Sangihe lebih memperhatikan lagi mengenai aset tetap, sehingga untuk tahun anggaran berikutnya, penggunaan aset tetap dapat menyajikan Laporan Keuangan yang sesuai dengan Standar Akuntansi Pemerintahan.

\section{DAFTAR PUSTAKA}


Arif, Bahtiar, dkk. 2009. Akuntansi Pemerintahan. Jakarta : PT. Indeks.

Badan Pemeriksa Keuangan Republik Indonesia. 2009. Ikhtisar Hasil Pemeriksaan Semester I Tahun 2009.

Bastian, Indra. 2006. Akuntansi Sektor Publik: Suatu Pengantar. Jakarta : Penerbit Erlangga.

Halim, Abdul. 2007. Akuntansi Keuangan Daerah. Edisi 3. Jakarta : Salemba Empat.

Hartina, Silka, 2009. Analisis Penyajian Laporan Keuangan Daerah pada Pemerintah Kabupaten Langkat. Skripsi Fakultas Ekonomi Universitas Sumatera Utara. Medan.

Hasan, Iqbal. 2008. Analisis Data dan Penelitian dengan Statistik. Jakarta : Bumi Aksara.

Hidayah, Nurul. 2010. Akuntansi Sektor Publik Pemerintah dan Swasta. Modul Universitas Mercu Buana. Jakarta.

Horngren T, Charles, dkk. 2006. Akuntansi, jilid 1, Edisi Bahasa Indonesia. Jakarta : PT. Indeks Kelompok Gramedia.

Indrianto, N, Supomo, B. 2002. Metodologi Penelitian Bisnis. Yogyakarta : BPFE.

Kuncoro, Mudrajad. 2003. Metode Riset untuk Bisnis dan Ekonomi. Jakarta : Erlangga.

Mardiasmo. 2002. Akuntansi Sektor Publik. Yogyakarta : Penerbit Andi. 